\title{
PEMBUATAN WEBSITE KAMPOENG HERITAGE KAYUTANGAN SEBAGAI MEDIA PROMOSI UNTUK MENINGKATKAN EKONOMI RAKYAT DALAM SEKTOR EKONOMI KREATIF
}

\author{
Febriana Santi Wahyuni ${ }^{1}$, Irmalia Suryani Faradisa ${ }^{2}$,Budi Fathony ${ }^{3}$ \\ 1 Teknik Informatika, Institut Teknologi Nasional Malang \\ 2 Teknik Elektro, Institut Teknologi Nasional Malang \\ ${ }^{3}$ Arsitektur, Institut Teknologi Nasional Malang \\ vebryana@lecturer.itn.ac.id
}

\begin{abstract}
ABSTRAK
Malang Raya adalah suatu wilayah terdiri dari tiga wilayah meliputi Kota Malang, Kabupaten dan Kota Batu. Kayutangan merupakan suatu kawasan yang terletak di kelurahan Kauman Kota Malang Jawa Timur. Selain memiliki nilai sejarah, daerah ini juga merupakan pusat pertokoan dan perdagangan di Kota Malang. Oleh karena itu daerah tersebut dapat dikembangkan menjadi tempat wisata yang potensial. Kampong Heritage merupakan satu daerah di wilayah Kayutangan tepatnya di Jl. Arif Rahman Hakim gg II, Kauman, Kec. Klojen, Kota Malang, Jawa Timur 65119. Terdapat banyak peninggalan sejarah di daerah tersebut berupa rumah tua yang bernuansa kolonial, taman dolanan dan barang-barang antik yang masih disimpan dan dirawat dengan baik oleh warga kampung tersebut. Hal ini memunculkan ide kreatif warga sekitar untuk melestarikan warisan sejarah tersebut dengan cara membuka daerah tersebut sebagai tempat wisata yang kemudian banyak dikenal sebagai Kampoeng Heritage. Dengan pengembangan destinasi wisata Kampung Heritage Kayutangan, diharapkan dapat meningkatkan sektor ekonomi kreatif. Hal ini sesuai dengan harapan pemerintah supaya masyarakat dapat menggali ide-ide kreatifnya untuk meningkatkan taraf hidup masyarakat disekitar tempat wisata. Bertujuan untuk memperluas penyebaran informasi mengenai tempat wisata ini dikembangkan satu website yaitu kampoengheritage.web.id. Website ini dikembangkan dengan menggunakan program PHP dan database My SQL, adapun fitur-fitur yang dikembangkan disesuaikan dengan kebutuhan tentang informasi yang ingin disampaikan kepada masyarakat luas. Berdasarkan pengujian yang dilakukan pada website diperoleh kesimpulan fungsi-fungsi yang ada pada website baik backend side maupun frontend side dapat berjalan sesuai dengan rancangan yang dibuat. Fitur-fitur pada website dapat berjalan baik pada browser Mozilla, Google Chrome dan Opera.
\end{abstract}

\section{Keyword : Media Promosi, Kampung Heritage Kayutangan, Ekonomi Kreatif}

\section{PENDAHULUAN}

Kampoeng Heritage merupakan satu daerah di wilayah Kayutangan tepatnya di J1. Arif Rahman Hakim gg II, Kauman, Kec. Klojen, Kota Malang, Jawa Timur 65119. Pemerintah Kota Malang menetapkan Kampung Kayutangan ini sebagai kawasan budaya (heritage) pada 22 April 2018. Kampoeng Heritage Kayoetangan merupakan kampung wisata tematik yang mengusung konsep suasana tempo dulu, mulai dari perabot, aksesoris rumah sampai kehidupan keseharian. Terdapat banyak peninggalan sejarah di daerah tersebut berupa rumah tua yang bernuansa kolonial, taman dolanan dan barang-barang antik yang masih disimpan dan dirawat dengan baik oleh warga kampung tersebut. Hal ini memunculkan ide kreatif warga sekitar untuk melestarikan warisan sejarah tersebut dengan cara membuka daerah tersebut sebagai tempat wisata yang kemudian banyak dikenal sebagai Kampoeng Heritage. Dengan pengembangan destinasi wisata Kampung Heritage Kayutangan, diharapkan dapat meningkatkan sektor ekonomi kreatif. Hal ini sesuai dengan harapan pemerintah supaya masyarakat dapat menggali ideide kreatifnya untuk meningkatkan taraf hidup masyarakat disekitar tempat wisata. Dan jika dikelola dengan baik tidak menutup kemungkinan dapat menjadi destinasi wisata internasional. Namun sangat disayangkan bahwa pengelolaan tempat wisat ini belum maksimal, bahkan belum diketahui oleh warga sekitar nya sebagai destinasi wisata, sehingga diperlukan pengelolaan tempat wisata yang lebih baik [1]. Sebagai upaya untuk memperluas penyebaran informasi mengenai tempat wisata Kampoeng Heritage Kayoetangan ini, dikembangkan satu website sebagai media promosi dengan harapan informasi dapat tersampaikan lebih luas lagi.

Kegiatan pengabdian masyarakat ini berdasarkan pada hasil penelitian dari Lalu Mulyadi, Budi Fathony dan Ester Priskasari yang tertuang pada monograf Potensi Kampung Heritage Kayutangan. Di Kayutangan terdapat berbagai potensi wisata dengan klasifikasi yang cukup lengkap. Klasifikasi ini meliputi wisata bangunan colonial, wisata kuliner yaitu Toko Oen dan Sate Gebug. Selain itu terdapat wisata budaya yang meliputi Oeklam-Oeklam Heritage, Topeng Malangan dan Festifal Mbois. Dan yang terakhir adalah wisata Open Space dan Sculpture dan wisata 
religi. Dengan banyak nya jenis wisata yang terdapat di Kampung Heritage Kayutangan ini berpotensi untuk menjadi cagar budaya dan kawasan destinasi wisata. [2].

\section{TINJAUAN PUSTAKA}

Menurut Ahyuna, M. Djabir Hamzah dan M. Najib HM dalam penelitian Pemanfaatan Internet Sebagai Media Promosi Pemasaran Produk Lokal Oleh Kalangan Usaha Di Kota Makassar menyimpulkan bahwa pemasaran langsung dengan menggunakan media internet akan lebih bermanfaat dibandingkan denagn melakukan pemasaran langsung secara konvensional. Hal ini dikarenakan penggunaan internet dalam pemasaran langsung lebih efektif dan efisien. [3]

Menurut Penda Sudarto Hasugian dalam penelitian Perancangan Website Sebagai Media Promosi Dan Informasi menyimpulkan bahwa website dapat membantu dalam memasarkan dan mempublikasikan produk, berita, diskon, kegiatan dan lain sebagainya. Website sesuai jika digunakan sebagi media promosi dan informasi. [4]

Menurut Nove E. Variant Anna dalam penelitian Penggunaan Web 2.0 sebagai Media Promosi Perpustakaan Perguruan Tinggi di Indonesia membuat kesimpulan bahwa penggunaan website sebagai media promosi pada kegiatan perpustakaan digunakan untuk menjalin hubungan atau komunikasi dengan pengguna. [5]

Beberapa penelitian tersebut menyimpulkan bahwa keberadaan suatu website dapat digunakan sebagai media promosi yang tepat di era teknologi sekarang ini.

\section{METODE PELAKSANAAN}

Rencana kegiatan dilakukan dalam beberapa langkah meliputi persiapan, pelaksanaan dan pemeliharaan.

a. Tahap persiapan yaitu pengumpulan data yang dilakukan dengan cara survey ke lapangan dan wawancara dengan pihak terkait.

b. Tahap Pelaksanaan pada tahap ini terdiri dari beberapa tahap yaitu analisis, perancangan, implementasi dan pengujian. Diawali dengan tahapan analisis yaitu menentukan kebutuhankebutuhan fungsional dari website yang akan dibuat, dari hasil analisis berikutnya adalah tahap perancangan dimana pada tahap ini dilakukan perancangan struktur menu, database dan layout. Setelah itu dilanjutkan ke tahap implementasi berdasarkan dari hasil perancangan pada tahap sebelumnya. Website dikembangkan menggunakan bahasa pemrograman PHP dan database My SQL. Dan tahap terakhir adalah tahapan pengujian dimana dilakukan dengan menggunakan black box testing yaitu pengujian berdasarkan fungsi dari perangkat lunak yang dikembangkan. c. Tahap Pemeliharaan yaitu tahapan yang dilakukan untuk membuat website berada pada performa yang optimal dan memperbaiki kesalahankesalahan atau ketidaksesuaian fitur.

Partisipasi mitra dalam pelaksanaan kegiatan ini adalah membantu dalam penyediaan dan melengkapi data-data yang diperlukan berupa foto-foto kegiatan, kebutuhan-kebutuhan fungsional dari website sehingga dapat sesuai dengan yang diharapkan dan masukanmasukan konten apa saja yang sebaiknya ada dalam website yang akan dikembangkan.

Evaluasi program dan keberlanjutan program setelah kegiatan PKM selesai dilaksanakan dengan melakukan pemantauan website berkaitan dengan kemutakhiran konten dan melakukan transfer ilmu tentang maintenance website secara berkala kepada pengurus wisata Kampoeng Heritage sehingga nantinya dapat melakukan secara mandiri.

\section{HASIL DAN PEMBAHASAN}

Hasil dari kegiatan pengabdian kepada masyarakat ini adalah suatu website yang memiliki beberapa fitur. Adapun fitur-fitur yang terdapat dalam website Kampung Heritage Kampoeng Kajoe Tangan meliputi menu registrasi, menu login, menu beranda, menu event, menu kuliner, menu akomodasi, menu gallery, menu tentang kita dan menu testimony. Adapun fungsi dan penjelasan dari masing-masing menu adalah :

a. Menu Registrasi

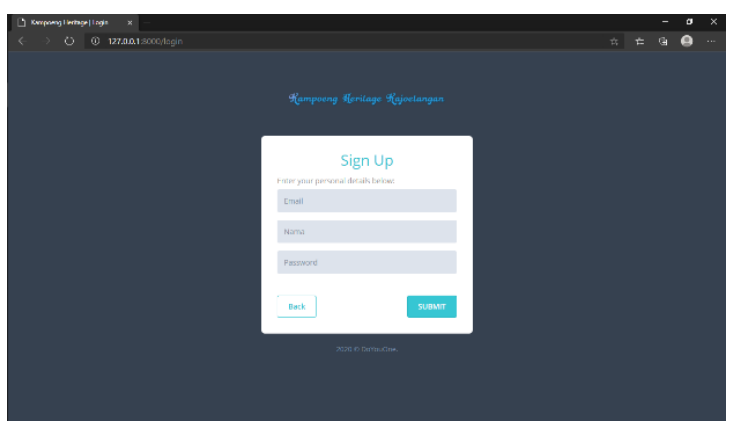

Gambar 1. Tampilan Halaman Registrasi

Fitur registrasi digunakan untuk mendaftar sebagai Admin. Pada fitur ini user diminta untuk menginputkan data berupa email, username dan password.

\section{b. Menu Login}

Menu Login berfungsi untuk memberikan akses kepada user untuk dapat mengelola konten dari website. Adapun tampilan menu Login ditunjukkan seperti pada Gambar 2. 


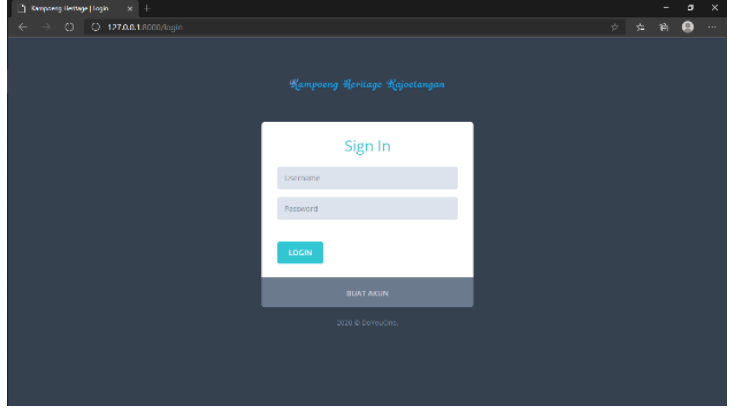

Gambar 2. Tampilan Menu Login

c. Menu Beranda

Pada menu beranda akan ditampilkan eventevent terbaru yang akan diadakan. Tampilan dari menu beranda ditunjukkan pada Gambar 3 .

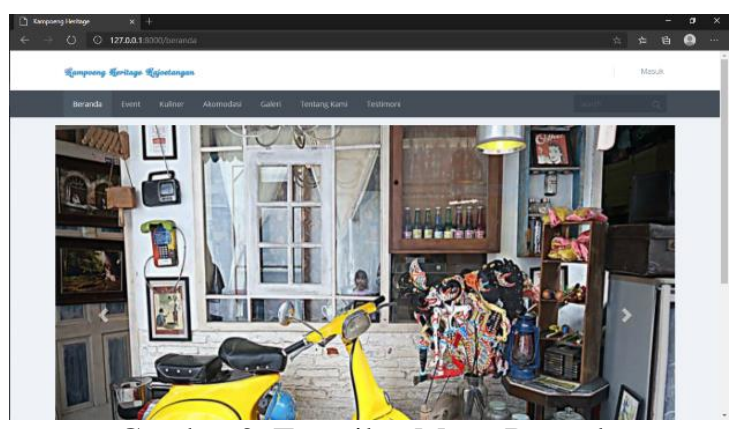

Gambar 3. Tampilan Menu Beranda

d. Menu Event

Menu event menampilkan mengenai event/acara yang akan diselenggarakan, dalam menu ini akan ditampilkan informasi mengenai event yang terdiri dari Judul Event, Tanggal, Jam, Penyelenggara, Deskripsi Kegiatan dan Foto. Tampilan menu event ditunjukkan pada Gambar 4.. Informasi detail dari satu event ditunjukkan pada Gambar 5.

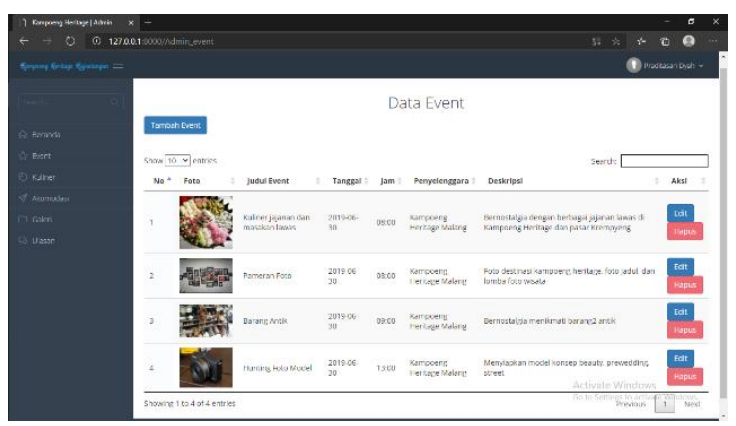

Gambar 4. Tampilan Menu Event

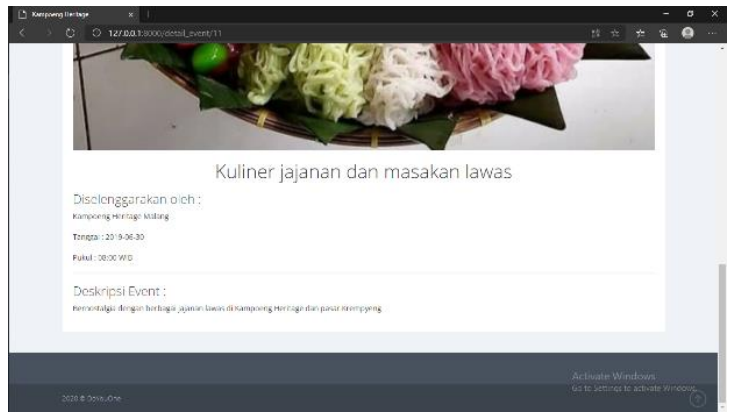

Gambar 5. Tampilan Detail Dari Salah Satu Event

e. Menu Kuliner

Pada menu kuliner di tampilkan berbagai jenis kuliner yang terdapat disekitar lokasi wisata. Adapun menu kuliner ditunjukkan pada Gambar 6, data detail dari menu kuliner dapat dilihat pada Gambar 6.

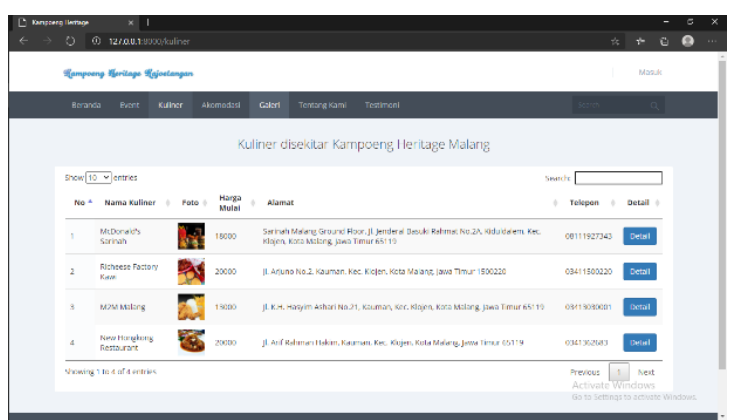

Gambar 6. Tampilan Menu Kuliner

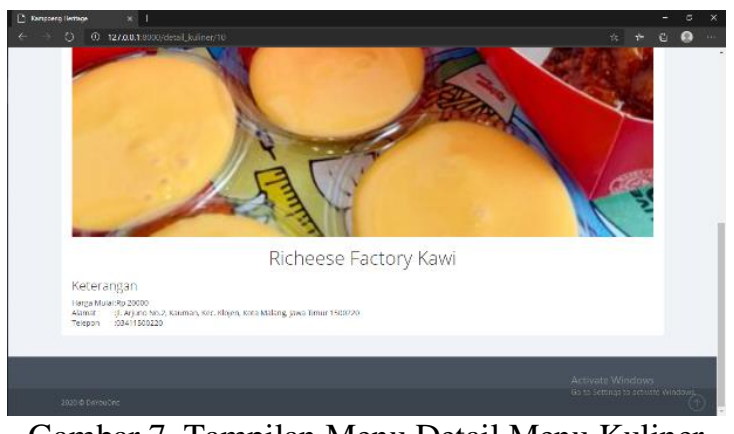

Gambar 7. Tampilan Menu Detail Menu Kuliner

\section{f. Akomodasi}

Menu selanjutnya adalah Menu Akomodasi, pada menu ini ditampilkan akomodasi yang berada disekitar lokasi tempat wisata. Pada menu akomodasi ini ditampilkan informasi mengenai nama, alamat, harga dan foto, menu akomodasi ditunjukkan pada Gambar 8. Informasi detail dari data akomodasi ditunjukkan pada Gambar 9. 


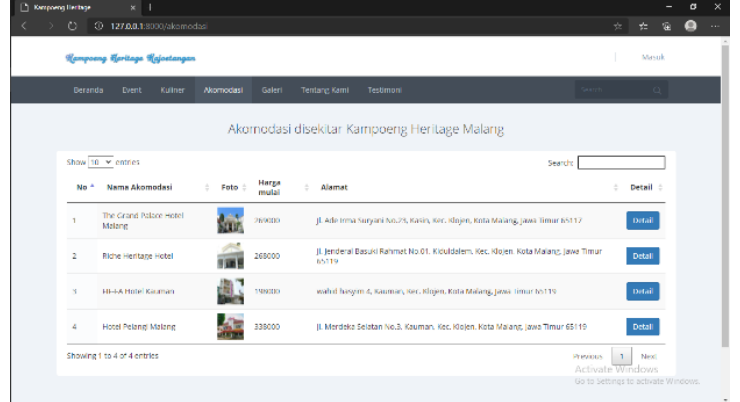

Gambar 8. Tampilan Halaman Menu Akomodasi

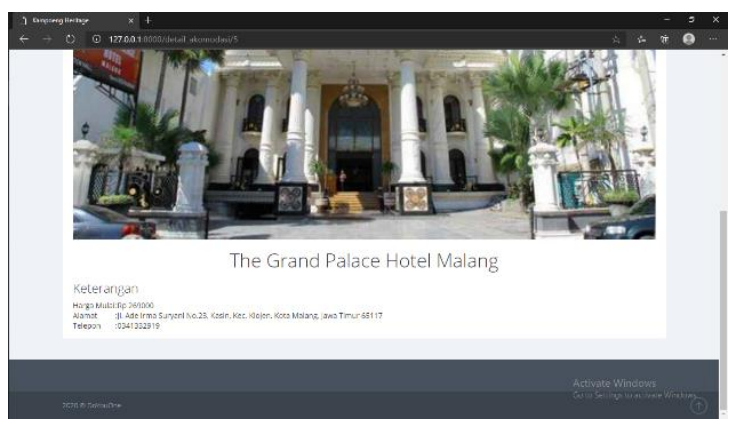

Gambar 9. Tampilan Halaman Akomodasi Detail

\section{g. Gallery}

Menu Gallery berisi foto-foto yang ada di tempat wisata, Tampilan dari menu gallery ditunjukkan Gambar 10, detail dari satu foto ditunjukkan pada Gambar 11.

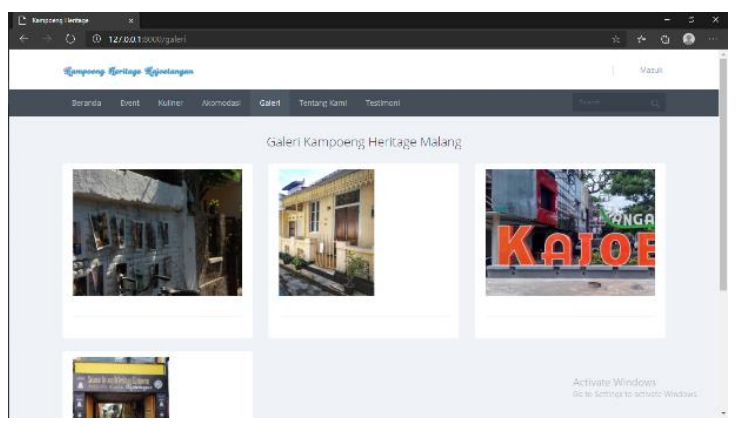

Gambar 10. Tampilan Halaman Menu Gallery

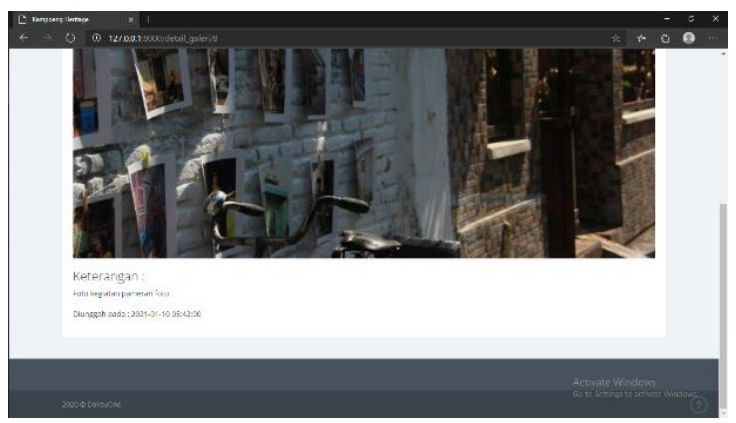

Gambar 11. Tampilan Halaman Menu Gallery Detail

h. Tentang Kami

Pada menu tentang kami menampilkan informasi-informasi mengenai wisata Kampoeng Heritage Kayoe Tangan berupa alamat, rute, tiket masuk dan Peta. Menu tentang kami ditunjukkan pada Gambar 12 dan Gambar 13.

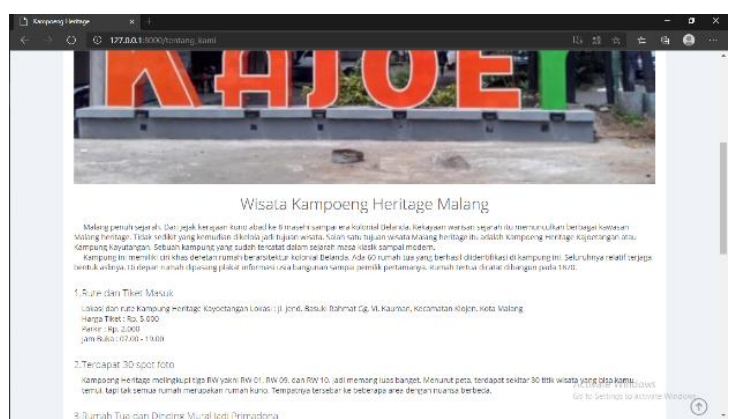

Gambar 12. Tampilan Halaman Menu Tentang Kami

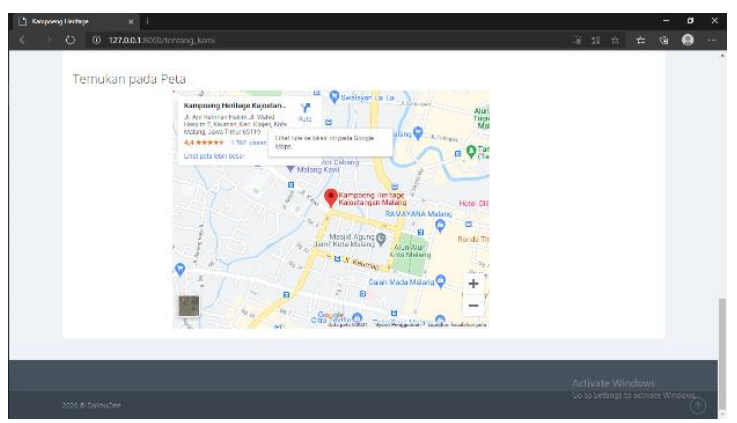

Gambar 13. Tampilan Peta Pada Menu Tentang Kami

i. Testimoni

Menu terakhir dari website ini adalah menu testimony, dalam menu testimony pengunjung dapat memberikan ulasan mengenai tempat wisata. Menu testimony ditunjukkan pada Gambar 14.

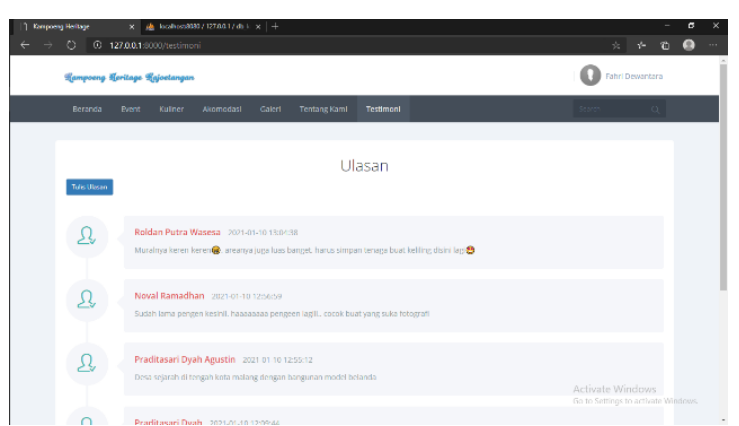

Gambar 14. Tampilan Halaman Menu Testimoni

Pengujian sistem dilakukan dengan menggunakan pengujian Blackbox yaitu pengujian yang dilakukan dengan cara mengamati hasil eksekusi program (running program) apakah sesuai atau tidak dengan rancangan yang dilakukan sebelumnya. Pengujian dilakukan pada sisi backend dan frontend. Frontend dari suatu website adalah bagian dimana user bisa melihat dan berinteraksi secara langsung dengan website. Sedangkan backend adalah bagian belakang layar dari suatu website, biasanya dikelola oleh admin saja. Adapun hasil pengujian disajikan pada Tabel 1 
Tabel 1. Hasil Pengujian

\begin{tabular}{|c|c|c|c|c|c|}
\hline \multirow[b]{2}{*}{ No } & \multirow[b]{2}{*}{ Fungsi } & \multicolumn{2}{|c|}{ Mozilla Firefox } & \multicolumn{2}{|c|}{ Chrome } \\
\hline & & Sesuai & $\begin{array}{l}\text { Tidak } \\
\text { Sesuai }\end{array}$ & Sesuai & $\begin{array}{l}\text { Tidak } \\
\text { Sesuai }\end{array}$ \\
\hline \multicolumn{6}{|c|}{ BACK END } \\
\hline 1 & Tambah data event & $\checkmark$ & & $\checkmark$ & \\
\hline 2 & Edit data event & $\checkmark$ & & $\checkmark$ & \\
\hline 3 & Hapus data event & $\checkmark$ & & $\checkmark$ & \\
\hline 4 & $\begin{array}{l}\text { Tambah data } \\
\text { kuliner }\end{array}$ & $\checkmark$ & & $\checkmark$ & \\
\hline 5 & Edit data kuliner & $\checkmark$ & & $\checkmark$ & \\
\hline 6 & Hapus data kuliner & $\checkmark$ & & $\checkmark$ & \\
\hline 7 & $\begin{array}{l}\text { Tambah data } \\
\text { akomodasi }\end{array}$ & $\checkmark$ & & $\checkmark$ & \\
\hline 8 & $\begin{array}{l}\text { Edit data } \\
\text { akomodasi }\end{array}$ & $\checkmark$ & & $\checkmark$ & \\
\hline 9 & $\begin{array}{l}\text { Hapus data } \\
\text { akomodasi }\end{array}$ & $\checkmark$ & & $\checkmark$ & \\
\hline 10 & $\begin{array}{l}\text { Tambah data } \\
\text { gallery }\end{array}$ & $\checkmark$ & & $\checkmark$ & \\
\hline 11 & Edit data gallery & $\checkmark$ & & $\checkmark$ & \\
\hline 12 & Hapus data gallery & $\checkmark$ & & $\checkmark$ & \\
\hline 13 & $\begin{array}{l}\text { Tambah data } \\
\text { testimoni }\end{array}$ & $\checkmark$ & & $\checkmark$ & \\
\hline 14 & Edit data testimoni & $\checkmark$ & & $\checkmark$ & \\
\hline 15 & $\begin{array}{l}\text { Hapus data } \\
\text { testimoni }\end{array}$ & $\checkmark$ & & $\checkmark$ & \\
\hline \multicolumn{6}{|c|}{ FRONT END } \\
\hline 16 & Menu Home & $\checkmark$ & & $\checkmark$ & \\
\hline 17 & Menu Beranda & $\checkmark$ & & $\checkmark$ & \\
\hline 18 & Menu Kuliner & $\checkmark$ & & $\checkmark$ & \\
\hline 19 & Menu Akomodasi & $\checkmark$ & & $\checkmark$ & \\
\hline 20 & Menu Gallery & $\checkmark$ & & $\checkmark$ & \\
\hline 21 & Menu Tentang Kita & $\checkmark$ & & $\checkmark$ & \\
\hline 22 & Menu Testimone & $\checkmark$ & & $\checkmark$ & \\
\hline
\end{tabular}

\section{KESIMPULAN DAN SARAN}

\subsection{Kesimpulan}

Dari pengujian black box yang telah dilakukan pada website, dapat diambil beberapa kesimpulan yaitu :

1. Fungsi-fungsi pada website baik backend side maupun frontend side dapat berjalan sesuai yang diharapkan.
2. Fungsi-fungsi pada website dapat berjalan baik pada browser Mozilla, Google Chrome dan Opera.

\subsection{Saran}

Untuk pengembangan website dapat di tambahkan fitur pencarian jarak terdekat serta jenis akomodasi yang dapat dipilih dari lokasi pengguna secara realtime.

\section{DAFTAR PUSTAKA}

[1] Ahyuna, M. Djabir Hamzah dan dan M. Najib HM, 2013, Pemanfaatan Internet Sebagai Media Promosi Pemasaran Produk Lokal Oleh Kalangan Usaha Di Kota Makassar, Jurnal Komunikasi KAREBA Vol. 2, No.1 Januari Maret 2013, Jurusan Ilmu Komunikasi FISIP UNHAS, Makasar.

[2] Anna, Nove E. Variant, 2015, Penggunaan Web 2.0 sebagai Media Promosi Perpustakaan Perguruan Tinggi di Indonesia, Record And Library Journal, Volume 1, Nomor 1, Januari Juni

[3] Hasugian, Penda Sudarto, 2018, Perancangan Website Sebagai Media Promosi Dan Informasi , Journal Of Informatic Pelita Nusantara Volume 3 No 1 Maret 2018 e-ISSN 2541-3724, STMIK Pelita Nusantara, Medan

[4] Khakim, Moch. Nurfahrul Lukmanul, dkk., 2019. Urgensi Pengelolaan Pariwisata Kampung Heritage Kajoetangan Malang., JTP2IPS (2019) volume 4 hal 15-22., Universitas Negeri Malang.

[5] Mulyadi, Lalu., Budi Fathoni dan Ester Prikasari,2019, Potensi Kampung Heritage sebagai Destinasi Wisata Kota Malang, Deazha, Malang. 